\title{
Article \\ Closing the Gap between Graduates' Skills and Employers' Requirements: A Focus on the Strategic Management Capstone Business Course
}

\author{
Meredith E. David ${ }^{1, *}$, Fred R. David ${ }^{2}$ and Forest R. David ${ }^{3}$ \\ 1 Marketing Department, Baylor University, Waco, TX 76798, USA \\ 2 Business Administration Department, Francis Marion University, Florence, SC 29506, USA; \\ fdavid@fmarion.edu \\ 3 Faculty of Economics and Business, University of Debrecen, H-4032 Debrecen, Hungary; \\ forestdavid5@gmail.comc \\ * Correspondence: meredith_david@baylor.edu
}

Citation: David, Meredith E., Fred R. David, and Forest R. David. 2021. Closing the Gap between Graduates' Skills and Employers' Requirements: A Focus on the Strategic Management Capstone Business Course.

Administrative Sciences 11: 10. https://doi.org/10.3390/ admsci11010010

Received: 8 January 2021

Accepted: 24 January 2021

Published: 26 January 2021

Publisher's Note: MDPI stays neutral with regard to jurisdictional claims in published maps and institutional affiliations.

Copyright: (c) 2021 by the authors. Licensee MDPI, Basel, Switzerland. This article is an open access article distributed under the terms and conditions of the Creative Commons Attribution (CC BY) license (https:// creativecommons.org/licenses/by/ $4.0 /)$.

\begin{abstract}
Strategic management has long been the capstone course for business majors at most colleges and universities globally. As originally designed, the capstone course sought to teach students an array of skills and tools needed to actually perform strategic planning, primarily through integration and application of functional business concepts and techniques. Times have changed, however, and business schools have come under scrutiny regarding their ineffectiveness in developing graduates' skills commensurate with employers' requirements. Such criticism is justified as academics teaching the capstone business course have partitioned their instruction efforts to focus increasingly on theory rather than practical applications. After a pertinent evaluation of current academic research, we illuminate how and why increased focus on practice is needed in strategicmanagement pedagogy. We delineate how the once well-designed business capstone course has evolved into a course that too often fails to impart practical competencies to graduating students. To facilitate closing the gap between graduates' skills and employers' requirements, we present a strategic management pedagogical model designed to promote student learning and development of hard and soft skills related to actually doing strategic planning. The proposed model can help reduce the gap between graduates' skills and employers' requirements with the intended purpose to provide increased interest for teaching practical tools that were developed by practitioners. Such tools include the BCG matrix, developed by the Boston Consulting Group, and the Internal-External (IE) portfolio matrix derived from the General Electric (GE) Business Screen developed by Jack Welch, former CEO of GE. The proposed model also reveals the process of including both internal and external aspects into strategic decision making as evidenced by countless organizations performing Strength-Weakness-Opportunity-Threat (SWOT) analyses. The proposed model significantly enhances previous theory-based approaches for teaching the capstone strategic-management course.
\end{abstract}

Keywords: strategic management; business pedagogy; employability; management competencies; teaching strategy; strategic planning; capstone course; case analysis; applying tools and skills

\section{Introduction}

The preponderance of literature in management journals in the last decade largely aligns with Mintzberg's (2004) "theoretical" approach to teaching strategic management that largely disregards the process, tools, and techniques that companies and organizations actually utilize in doing strategic planning. Consistent with Mintzberg's perspective, for example, Bell et al. (2018, p. 233) stated, "strategic-management courses today are criticized for being repositories of multiple frameworks that are not tightly integrated and are aging rapidly while concerns have been voiced about the lack of effectiveness of strategic management education." Reflecting the growing concerns of business education, 
the September 2018 special issue of the Academy of Management Learning and Education $(A M L E)$ was "devoted to addressing the increasingly frequent calls for more relevant and practically applicable strategy education" (Bell et al. 2018, p. 233). Similarly, and more recently, Alamo-Vera et al. (2020) examined study-abroad programs and concluded that these programs help close the gap between graduates' skills and employers' requirements. The purpose of this paper is to examine the capstone business course and develop and propose an improved model aiding strategy professors and strategy students alike as we strive to bridge the gap between graduates' skills derived from successful completion of the strategy class and employers' requirements.

Prior research advocates a need for more integration of practice into the capstone strategic management course but provides scant direction for accomplishing this objective. For example, there is no mention among the nine special issue $A M L E$ articles regarding how any company actually does (or should do) strategic planning, much less whether strategic management students should learn how to do strategic planning. A rethinking of management education is perhaps needed because the corporate world increasingly values employability skills, and in the academic world, many marketing, finance, and accounting professors expect the "capstone" course to be an opportunity for students to apply previously learned (and new) business skills. We address this omission and the important question of whether strategy classes should be structured more toward practical applications or theoretical underpinnings.

In the sections that follow, we suggest that strategic management courses be taught in a more practical manner that follows the corporate strategic planning process and showcases the steps and skills that many if not most organizations actually utilize in formulating, implementing, and evaluating strategies (David et al. 2020, p. 21). This paper seeks to spur a shift in strategic management to align theory more effectively with practice in the classroom. This realignment is needed as evidenced in recent articles ubiquitously and implicitly concluding that the capstone strategy course be taught in a highly theoretical manner, largely absent of any tools and techniques utilized in the actual practice of strategic planning (Buckley 2018; Hanney 2018; Hansen 2011; Lebron et al. 2020).

Strategic Management has historically been the integrative, capstone course (originally called Business Policy) for business majors at most universities globally. As originally designed, this course sought to teach students the skills and tools needed to actually do strategic planning. The evolution from business policy to strategic management over the last four decades however witnessed a precipitous shift to theory away from practice in the capstone course (Bower 2008; Grant and Baden-Fuller 2018, p. 323; Thomas 1998). Strategic Management is still well known at colleges and universities globally with the status that comes with being considered the "capstone" course (Rippin et al. 2002). However, strategy theorists have somewhat "hijacked" the capstone aspect of the course by giving students limited to no opportunity to apply functional level business skills in preparing strategic plans or doing case analysis (Campbell et al. 2006; Donaldson 2002; Grant 2008).

Our experiences over decades in both teaching the capstone course and assisting businesses in doing strategic planning align well with Pfeffer and Long (2002) in that strategic management students should learn strategic-planning tools, techniques, and concepts that mirror quite closely what businesses are actually doing-just as is done in dentistry, nursing, architecture, and other professional disciplines. Herein we propose an effective skills-based model that could help close the gap between graduates' competencies and employers' expectations as needed in the 21st century.

\section{Teaching Strategic Management}

Practical strategic planning skills such as developing effective vision and mission statements, performing Strength-Weakness-Opportunity-Threat (SWOT) analysis, Boston Consulting Group (BCG) analysis, and Quantitative Strategic Planning Matrix (QSPM) analysis, and developing projected financial statements to show the impact of a proposed strategic plan, represent "hard" skills that are valued by businesses more than knowledge 
of agency theory, institutional theory, and other similar concepts. These skills are commonly used by practicing managers and executives in businesses around the world. As strategy students learn "how to do strategic planning," they also gain practice using tools learned in previous business courses, such as marketing's perceptual mapping, finance's EPS-EBIT analysis and corporate valuation, and management's organizational structure. Thus, in learning how to develop a strategic plan for a wide variety of organizations, students develop, learn, and refine numerous employability skills that are increasingly valued in the marketplace.

In order to narrow the gap between graduates' skills and employers' requirements, we believe strategic management students should indeed learn how to do strategic planning, for three important reasons. First, management education is about learning "how to do" rather than learning "how to theorize." In fact, Grant and Baden-Fuller (2018, p. 324) state:

"What is the purpose of the core strategic management course? Management is not an intellectual pursuit, it involves doing. So, with strategic management, 'Strategy is about action' states Richard Rumelt (2011, p. 87)".

Second, the "how to do" approach enables students to practice, apply, and enhance their functional-level business skills obtained largely in prior business courses, as the word "capstone" suggests will be done. Third, the "how to do" approach facilitates students gaining new strategic planning specific employability skills.

Prior articles speak extensively about the need to integrate more practice in the teaching of strategic management (Berdrow and Evers 2010; Marsh and Bishop 2014). For example, Bell et al. (2018, p. 236) state:

"We suggest that strategy education research evaluate how decision-making styles can be integrated with popular strategy tools including Porter's Five Forces and value chain analyses, SWOT (strengths, weaknesses, opportunities, threats), and VRIO (value, rarity, imitability, organization) frameworks, and portfolio matrices, among others".

However, prior articles rarely ever expand on a sentence like this with specifics aimed at narrowing the gap between graduates' skills and employers' requirements. This is problematic because as students learn the "how to", they simultaneously are given the opportunity in the capstone course to learn new and apply previously learned functional business employability skills. The Grant and Baden-Fuller (2018, p. 322) article says:

"The dominance of theory-based approaches to teaching strategy has not displaced the need for core courses in strategic management to cultivate broader management skills. Yet, limited attention has been given to explicating, first, why we need to teach these skills; second, which skills we need to teach; and third, how they can be developed in the classroom."

However, after this sentence, the Grant and Baden-Fuller (2018) article devotes the rest of the paper to advocating development of "soft" skills among strategy students, including creativity, communication, emotional ambiance, engagement, and systems thinking, rather than identifying any "hard" skills actually being used by companies in doing strategic planning.

\section{Strategic Management Theory}

The narrative in management journals in the last decade, especially in top-tier journals, largely aligns with Mintzberg's (2004) "theoretical" approach to teaching strategic management that largely disregards the process, tools, and techniques that companies and organizations actually utilize in doing strategic planning. Mintzberg (2004) says teaching strategic management students how to do strategic planning equates to going through, as Bell et al. (2018, p. 233) call it, "a kit or bag of analytic techniques that are often inadequate and irrelevant for effective strategic thinking."

Buckley (2018) advocates that teaching strategic management actually needs substantially more theory. Such theorists are seemingly comfortable with strategic management 
students leaving the capstone course as they entered it, not knowing how businesses do strategic planning and not having gained any new, or practiced any old, hard strategicbusiness skills. For example, Buckley $(2018$, p. 339) states: "the prevailing form of strategy teaching is under-theorized; I suggest that attention to theory, more characteristic of international business, can improve strategic-management teaching and education; specifically, strategic management can draw on theory as a guide to action." Buckley (2018, p. 353) summarizes by identifying three philosophical approaches to education and learning in strategic management:

"1. Present the course as the test of the hypothesis that firms differ and that the critical reason for this is that managements (management decisions) differ.

2. Challenge students to find why and how firms differ and how far this can be related to management decisions.

3. Set up the strategic management course as a voyage of discovery where learners (and educators) together explore the differences and similarities in firms across a broad range of contexts".

Priem (2018) advocates integration of more practice into the capstone course, but when the article suggests how to achieve the integration, it aimlessly says to "improve students' critical thinking." No "hard" skills are mentioned. Priem (2018) advocates the most effective way to improve students' critical thinking is to utilize innovative teaching tools like "flipping" the classroom, examining past and current strategy narratives, evidence-based management, and case studies in order to "nudge" strategy students onto a continuing path of improving their critical thinking. Aiming to enhance students' critical-thinking skills can help close the gap between theory and practice in strategic management pedagogy (Pilz and Zenner 2018).

Barney and Mackey (2018, p. 359) propose that two theories dominate strategicmanagement pedagogy: (1) structure-conduct-performance (SCP) theory (Porter 1980) and resource-based theory (RBT) (Barney 1991). Barney and Mackey (2018, p. 359) assert that "firms that try to apply both approaches to profit generation at the same time within the same business are likely to be unsuccessful." This contention is in direct contrast to the concept of "matching external with internal factors" in generating feasible alternative strategies as is evidenced in both SWOT and portfolio analysis. Barney and Mackey (2018, p. 360) propose that the core thrust in teaching strategic management is to help students understand when one theory (SCP or RBV) applies versus the other. However, strategic planning, from a practical perspective, is less about identifying the better theoretical approach, and rather, more about matching external with internal factors in formulating strategies (du Toit 2016; Fehringer et al. 2006; Gunn and Williams 2007). It should be acknowledged that there are practical aspects of both the SCP and RBV theories (Schneider and Lieb 2004). For example, structure (SCP) is an especially important topic in strategy implementation, and RBV is especially important in performing an internal audit or assessment, as our literature (and corporate) derived integrative pedagogical model will reveal.

Recent publications suggest that teaching strategy theory dominates the podium in strategy classrooms. In the $A M L E$ special issue articles discussed earlier, substantial time is devoted to agency theory, resource-based view theory, and institutional theory. Agency theory states that managers act as "agents" to maximize their self-interest at the cost of owners outside the corporation, who lose value. Donaldson (2002) is a critic of agency theory, RBV theory, and institutional theory. He criticizes agency theory, saying:

"Agency theory posits that managers can lack the motivation to use new knowledge to maximize the performance of their organization; the theory describes means that could be used to control subordinates, but argues that pervasive agency problems make managers unlikely to adopt these needed controls". (Donaldson 2002, p. 104)

Educating managers (or students) in agency theory regarding the need for more controls is often viewed to be dysfunctional in terms of enhanced organizational performance 
(Jensen and Meckling 1976). However, agency theory can assuredly be helpful in evaluating and monitoring strategic plans, and future research, classroom lectures, and corporate strategic planning practice should address strategy evaluation and agency theory.

RBV theory holds that sustained competitive advantage comes from a firm having valuable resources that are rare, non-substitutable, and inimitable (Barney 1991). Barney (1995) distilled the resource-based view into the VRIO (value, rarity, inimitability, organization) framework. The emphasis of RBV theory is upon developing skills, technologies, administrative systems, or organizational cultures that are unique to the firm. However, Donaldson (2002, p. 98) is quite critical of RBV theory; for example, he says:

"Barney states "that many of the attributes of resources that make them likely to be sources of sustained strategic advantage-especially path dependence and social complexity—are not amenable to management manipulation" (2001, p. 49), so they cannot be amenable to management education".

Institutional theory is based on the thought that organizations are not about rationality, but about rituals and conformity to some ideology (DiMaggio and Powell 1983; DiMaggio and Powell 1991; Meyer and Rowan 1977). According to Donaldson (2002), institutional theory may encourage managers to be non-rational, adopt the wrong strategies and structures, be non-innovative, focus on impression management, downgrade operational effectiveness, and embrace fad and ideology. Donaldson (2002, p. 96) says: "institutional theory pictures organization as ritual more than rationality; the key function of managers is public relations, through manipulation of the truth in a way inimical to educational values."

Peng and colleagues (2018) focus on adding more "institutionalism" into the strategy classroom. For example, Peng et al. (2018, p. 260) state:

"Sociological institutionalism is sometimes called "organizational institutionalism", "institutional theory", or "sociological and organizational strands of (new) institutional theory." However, economic institutionalism theorists, such as Williamson, have called their stream "new organizational economics," and sometimes labeled theories such as transaction cost theories (TCE) "new institutional theory."

Institutional theories can be helpful in implementing strategies because corporate culture can significantly impact organizational performance. Institutional theory likely would reveal that people get attached to cultural products and norms and these must be considered in both formulating and implementing strategies (Boselie et al. 2005; Paauwe and Boselie 2007; Paauwe 2004). In this manner, institutionalism can be taught such that it actually assists students in learning how to develop and propose an effective strategic plan for a business. Thus, future research, classroom lectures, and corporate strategic-planning practices should address institutionalism.

Moschieri and Santalo (2018) suggest that a strategy professor's research publication record relates somehow to the issue of how best to teach strategic management. These authors report a significant positive association between research performance, measured by the number of publications in a 6-year interval, and students' evaluations of teaching. Any professor of any course is inclined in class to focus on what he/she knows and can do, but the capstone course in our opinion should enable students to learn "how to do strategic planning," rather than concentrating on learning about their professor's primary theoretical strategy research interest areas. Perhaps some strategy instructors are not aware of how businesses actually do strategic planning in terms of concepts, processes, tools, and techniques utilized, or perhaps in their heart they truly feel that strategy students should become theorists (Gonzalez et al. 2014). Moschieri and Santalo (2018) indirectly suggest that more theory is good for teaching the capstone course, and their "proof" is that in their sample, professors who get theory-based articles published tend to receive higher student evaluations. 
Bell et al. (2018, p. 233) state: "strategy educators, perhaps more than those in any other discipline, have an opportunity to teach students to search for the right questions rather than the right answers. We can teach them to be strategy theorists, themselves. After all, a strategy is primarily a theory of how competitive advantage can be achieved by a single firm." Bell et al. (2018, p. 235) state:

"If we can teach our students to approach a problem as scholars developing and testing their own theories, they might be less enamored of seductively simple, yet myopic answers to complex problems".

Theory is good to the extent that it enhances practice, and theory can enhance practice, but theory must not be an end itself, because that widens the gap between graduates' skills and employers' requirements, to the detriment of business education (Perera et al. 2017). Theory can teach students what to consider in their decision-making processes but it cannot effectively teach students how to do strategic planning any more than heavy accounting theory can teach a student how to balance a balance sheet. Donaldson (2002) contends that coverage of theories should warrant time in the classroom only if their independent variables are such that managers can influence them. He proposes that theories should not be given great amounts of attention in classrooms, because there is nothing managers can do with them; theories do not assist management education in attaining its goal of helping managers manage better. Donaldson (2002, p. 103) says: "management education does not fare well at the hands of strategy theory, agency theory, institutional theory, the theory of efficient markets, or judgmental bias theory".

\section{The Practice of Strategic Management}

Pfeffer and Long (2002, p. 84) note "a large body of evidence suggests that the curriculum taught in business schools has only a small relationship to what is important for succeeding in business." Ideally, business schools provide students the necessary training to compete favorably for jobs in the business world (David et al. 2011; Foster and Carboni 2009). Employability skills refer to actual tools, techniques, and concepts used by and valued by businesses in their hiring process. Experts say employability skills are vital for career success in the twenty-first-century workplace, and thus should be learned by college students studying from various textbooks. Business textbooks are more and more being expected to provide significant coverage of employability skills in respective disciplines, and strategic management is no exception (David et al. 2020, p. 21; Ghannadian 2013). Thus, in contrast to the Grant and Baden-Fuller (2018, p. 326) model, a framework is needed which is capable of integrating theory and skills appropriately across the stages involved in doing strategic planning.

Substantial literature suggests that employers increasingly seek graduates who possess a wide range of employability skills (Edudemic 2013; Forbes 2012; Mtawa et al. 2019; Rassuli et al. 2012). From a strategic management perspective, this paper identifies specific skill areas where more attention is needed in shaping and influencing business curriculum to meet employability needs. As early as 2005, Bennis and O'Toole in a Harvard Business Review article identified "How Business Schools Lost Their Way" and critics like Hansen (2011) said "Business Schools Have an Identity Crisis."

Historically, the term "ivory tower" came to symbolize the failure of business schools to adequately provide what the business world needs. Bennis and O'Toole (2005, p. 96) said, "business programs face intense criticism for failing to impart useful skills, failing to prepare leaders, and even failing to lead graduates to good corporate jobs." Reibstein et al. (2009) followed up discussing how and why business academia has lost its way. There remains today a divide between the training provided in many business courses and the needs of associated business jobs (Carson 2019; Sheehan et al. 2018). This situation hurts business students, schools, firms, and society at large, and motivated us to develop this critical perspective which aims to improve this situation.

It is worth noting that large companies generally scan incoming resumes by keywords to see if there is a match between the person's competencies and the job description needs 
(Hansen 2011). If a graduating senior in business administration, for example, does not have expertise in a particular skill area needed then it is unlikely that the person's resume will get an initial review. In this regard, graduates would have difficulty competing with others who have proficiency in areas cited in posted job descriptions. Students who graduate with specific employability skills have a competitive advantage over those who do not (Marsh and Bishop 2014; Pfeffer and Long 2002).

When students learn how to develop a strategic plan for a wide variety of organizations they concurrently develop, learn, and refine numerous employability skills that are valued in the marketplace. Hard, practical, strategic planning skills such as developing effective vision and mission statements, performing SWOT analysis, BCG analysis, and QSPM analysis, and developing projected financial statements to show the impact of a proposed strategic plan, represent skills that are valued by businesses (David et al. 2019; Frentzel et al. 2000; Wolf and Floyd 2017). Strategic management students generally are much less interested in becoming theorists than learning and applying practical strategic planning and functional-level business skills deemed to be helpful and important in the real world of business. Undergraduate and MBA strategic management students alike desire to learn how businesses actually do strategic planning, and in doing so learn new concrete employability skills and enhance their soft skills (such as communication, creativity, and critical thinking) during the process (Beard et al. 2008; French et al. 2015; Mtawa et al. 2019). Thus, a new strategic management pedagogical model is needed which offers direction and guidance for teaching the capstone course by incorporating both theory and practice appropriately across the stages of strategic planning (Bridgman et al. 2018).

The AACSB "strives to continuously improve engagement among business, faculty, institutions, and students so that business education is aligned with the needs of business practice" (AACSB 2020). Near the beginning of the AACSB website as of April 2020, the organization states: "the fundamental purpose of AACSB accreditation is to encourage business schools to hold themselves accountable for improving business practice through scholarly education and impactful intellectual contributions." Thus, even with theorybased articles and journals, we must strive to provide guidance, direction, and impetus for closing the gap between graduates' skills and employers' requirements.

Scholars who emphasize the development of managerially relevant cognitive and behavioral skills in strategic management pedagogy advocate a more "atheoretical" approach viewing the capstone course as an integrative, practice-based experience (Bower 2008; Gosling and Mintzberg 2004; Greiner et al. 2003; Mintzberg 2004; Ruth 2014). However, as Greiner, Bhambri, and Cummings observed over 15 years ago: "The traditional required Harvard Business School policy course is barely alive and in most top business schools the strategy course is heavily based upon theory and analysis" (Greiner et al. 2003, pp. 404-5).

Business schools need to respond to the needs of the workplace and provide students with opportunities to enhance their employability by learning important skills associated with actual strategic management. This is a huge opportunity for strategic management professors to explicitly consider and actively incorporate employability skills as they design course materials. As strategy students learn "how to do strategic planning," they also gain practice using tools learned in previous business courses, especially as related to strategy implementation, such as marketing's perceptual mapping, finance's EPS-EBIT analysis and corporate valuation, and management's organizational structure-fulfilling the "capstone" expectation of business school faculty from all disciplines (Campbell et al. 2006; Gilinsky and Robinson 2008).

\section{A Proposed Strategic Management Pedagogical Model}

The Grant and Baden-Fuller (2018, p. 326) model for teaching strategic management emphasizes development of soft skills to the exclusion of any hard skills. Their four-stage strategy process model includes: (1) situation appraisal and diagnosis, (2) strategic option generation, (3) strategic choice, and (4) strategy implementation. Grant and Baden-Fuller (2018) apply their model using the Bloom/Krathwohl's Taxonomy of Educational Objectives that 
culminate in five knowledge bases (metacognitive, procedural, conceptual, factual, and affective) and two domains (cognitive and affective). In discussing their model, the authors scantly mention SWOT analysis, the PEST framework, Porter's Five Forces of Competition, and Barney's VRIO frameworks.

The Grant and Baden-Fuller (2018, p. 326) model can be improved in three key ways: (1) elaborate upon the four-step process to reveal more clearly the best practices in doing strategic planning, (2) include relevant theories appropriately across the planning process to better assure effective integration of theory and practice in the capstone course, and (3) include both soft and hard strategic planning skills to meet both corporate and academician demands for an effective capstone course in business. Improvements to this model, to be illustrated below, can enable strategic management professors to narrow the gap between business graduates' skills and employers' requirements.

Given our literature review, practical experience, and teaching the capstone course, we propose the strategic management pedagogical model presented in Figure 1. Note in Figure 1 that across three stages of strategic management (formulation, implementation, and evaluation), appropriate soft skills, hard skills, and foundational theories are all arrayed as appropriate for emphasis and coverage in the capstone course. Note also in the proposed model for teaching the capstone course, there are arguably five theories, seven key steps, fourteen soft skills, and fourteen hard skills that should be considered for coverage (David et al. 2020; Grant and Baden-Fuller 2018). In actuality there are more than a hundred employability (soft and hard) business skills that could arguably be considered "strategic," so the skills cited in Figure 1 are just a sampling of important skills that should be considered for coverage in the capstone course (Edudemic 2013; Forbes 2012; Ghannadian 2013).

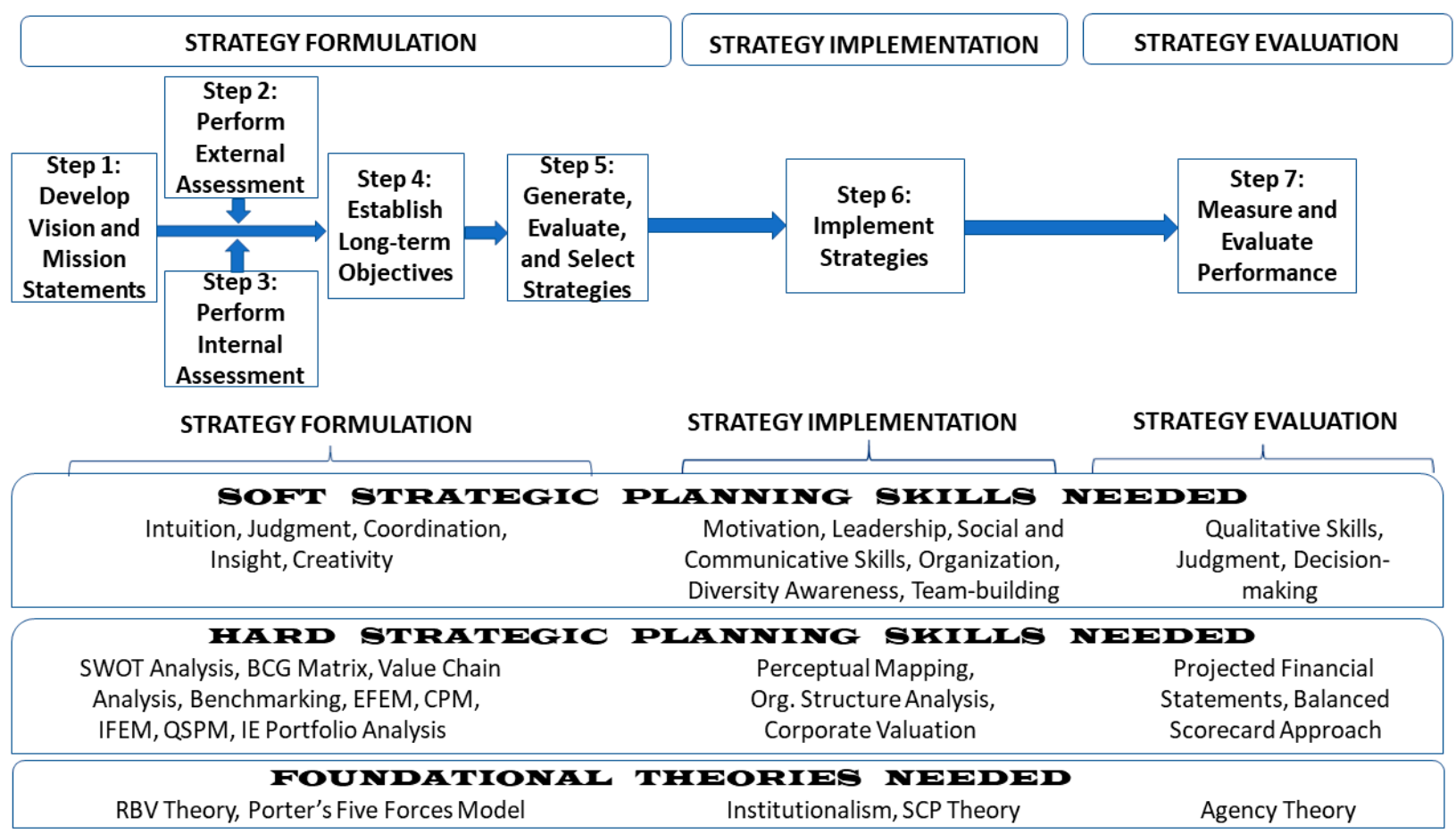

Figure 1. A proposed strategic management pedagogical model. Source: based on Grant and Baden-Fuller (2018, p. 326) and David et al. (2020, p. 2).

Note in the proposed model that learning and practicing hard skills such as SWOT, BCG, and QSPM analysis enable development of soft skills, such as critical thinking, diversity awareness, communication, and creativity that were mentioned in the $A M L E$ special issue articles. The steps and skills arrayed in Figure 1 are anchored in practice but 
supported by theory (Rassuli et al. 2012; Rendtorff 2015). The proposed model portrays a clear and practical approach for formulating, implementing, and evaluating strategies in a manner that many organizations actually use (David et al. 2020, p. 21; Strive and Grind 2013; Uyar and Gungormus 2011). Our proposed model is not an attack on theory; it simply suggests increased partitioning of time in teaching the undergraduate and MBA strategy course be devoted to practical aspects, rather than PhD-level theory. The strategic management process is dynamic and continuous; a change in any one of the steps can necessitate a change in any or all of the other components. The steps exhibited in the proposed model are not independent silos; they represent an interrelated process. In the sections below, we discuss the steps shown in Figure 1.

\subsection{Strategy Formulation}

Step 1 Develop an Effective Vision and Mission Statement

Most companies have a written vision and mission statement and consider the documents to be important. Prior strategic management literature is quite compelling in concluding that establishing a vision/mission is a vital first step in doing strategic planning. Although it would seem that strategic management students should learn how to develop vision and mission statements (Cochran and David 1986; David et al. 2016a; Pearce and David 1987), the words "vision" and "mission" never appear among most of the AMLE special issue articles, and appear only in passing when actually mentioned. Extensive prior research suggests a positive correlation between vision/mission and organizational performance (Boyd and Reuning-Elliott 1998; David et al. 2016a; Wolf and Floyd 2017).

Steps 2 and 3 Perform an External and Internal Assessment

A basic tenet of strategic management is that firms need to formulate strategies to take advantage of external opportunities and avoid or reduce the impact of external threats. For this reason, identifying, monitoring, and evaluating external opportunities and threats are essential for success. Even Mintzberg's design school diagram (1990) includes external opportunities/threats and internal strengths/weaknesses (p. 174). Internal strengths and weaknesses are an organization's controllable activities that are performed especially well or poorly. RBV theory is based on an internal assessment of the firm's capabilities (Barney 1991, 1995). Internal factors arise in the activities of management, marketing, finance/accounting, production, and information systems of a business. Although not included per se in the Grant model, external/internal assessment would be a part of their Stage 1 "situation appraisal and diagnosis."

\section{Step 4 Establish Objectives}

Objectives can be defined as specific results that an organization seeks to achieve in pursuing its mission. Objectives are essential for organizational success because they provide direction, aid in evaluation, foster synergy, reveal priorities, focus coordination, and provide a basis for effective planning, organizing, motivating, and controlling activities. Objectives should be challenging, measurable, consistent, reasonable, and clear (David et al. 2020, p. 13). Among the AMLE special issue articles, objectives or goals receive scant attention, yet establishing milestones is a key strategic planning activity widely practiced by firms and acknowledged to be vital for effective strategy evaluation. Not even in the Grant and Baden-Fuller (2018, p. 326) diagram that depicts "stages of the strategy process" is there mention or inclusion of objectives. Although not included per se in the Grant model, establishing objectives would presumably be a part of their Stage 2 "strategic option generation."

\section{Step 5 Develop Alternative Strategies and Select Strategies to Pursue}

The concept of "matching" is not discussed among the special issue articles, except that Barney and Mackey (2018, p. 367) demean the idea of matching saying "when a strategy professor uses SWOT from the 1970s that is merely a comparative list-making exercise that is 
(unfortunately) still practiced in some circles." Grant and Baden-Fuller (2018, p. 326) mention SWOT analysis but say it is a "purely classificatory device that is simply a set of 'buckets' for categorizing favorable and unfavorable internal and external influences". However, no strategy analyses, matrices, or portfolio analysis etc. are included in the Grant model per se, but presumably analyses such as BCG would be included in their Stage 3 "strategic choice."

A key to effective strategic planning in fact is "matching" - not trying to decide when external vs. internal forces are better. To propose exclusivity rather than matching in regards in to key external and internal factors in our experience reveals unawareness for the practice of strategic planning. As Donaldson (2002) implies in his critique of strategy theorists, training students to learn how to decide between when to use RBV vs. Porter's Five Forces model vs. agency theory vs. institutionalism is simply not relevant or related to how businesses actually formulate and implement strategic plans in the real world.

Mintzberg (1990) says: "the match between external and internal elements leads to the creation of strategies," but he mentions no tools for matching (p. 174). There are other matching tools widely used by companies in developing a strategic plan, such as portfolio analysis with inclusion of Boston Consulting Group (BCG) and the Internal-External (IE) analyses. The AMLE special issue articles never discuss BCG or IE. Portfolio analysis is critically important in strategic planning because allocating resources across divisions or segments (products or regions) is arguably the most important strategy decision made annually by companies and organizations.

Because no organization has unlimited resources, strategists must decide which alternative strategies will benefit the firm most. Strategy-formulation decisions commit an organization to specific products, markets, resources, and technologies over an extended period of time. Strategies determine long-term competitive advantages (Powell 1992). For better or worse, strategic decisions have major multifunctional consequences and enduring effects on an organization. Grant and Baden-Fuller (2018, p. 324) say: "we propose that the educational goal for the core strategic management course should be the following-Enhancing our students' abilities to make and execute strategic decisions." However, instead of striving in the capstone course to impart to students what Grant calls "the components of strategic management competency" (creativity, judgment, intuition, insight, familiarity with concepts and theories, social, and communicative skills), we additionally believe students in the capstone course should be given the opportunity to apply functional-level business skills learned in prior courses and learn new strategic planning specific employability skills. In this manner, academicians can most effectively close the gap between theory and practice in strategic management pedagogy.

One of the most commonly used strategic planning tools used by companies to make decisions is the QSPM (David 1986; David et al. 2016b). Presumably QSPM would in the Grant and Baden-Fuller (2018) model appropriately be a Stage 3 "strategic choice" analytical tool. QSPM analysis utilizes underlying key external and internal factors to determine the relative attractiveness of alternative strategies. No special issue article mentions the QSPM or any alternative method for assessing the relative attractiveness of feasible alternative strategies, such as various summed ranking approaches.

\subsection{Strategy Implementation}

Step 6 Implement Strategies

Mintzberg (1990) was correct when he asserted that strategy implementation is not separate from strategy formulation. Grant and Baden-Fuller $(2018$, p. 328) reiterate this fact by saying: "strategy-making is not a sequential process: strategies are formulated in the course of their implementation, and the formulation of strategy must take into account how it will be implemented." Indeed, strategy implementation often is called the "action stage" of strategic management. Implementing strategy means mobilizing employees and managers to put formulated strategies into action. The Grant model reveals no specific strategy implementation concepts, tools, or techniques commonly utilized by corporations in doing strategic planning. In contrast, the newly developed strategic 
management pedagogical model presented in Figure 1 includes several specific strategy implementation analyses that are recommended for coverage in the capstone course.

Often considered to be the most difficult stage in strategic management, strategy implementation requires personal discipline, commitment, and sacrifice. Successful strategy implementation hinges on managers' ability to motivate employees, which is more an art than a science. Strategies formulated but not implemented serve no useful purpose. Interpersonal skills are especially critical for successful strategy implementation. Strategy-implementation activities affect all employees and managers in an organization. Key implementation topics include organizational structure, culture, and diversity.

As noted in Figure 1, EPS/EBIT analysis is commonly used by publicly held companies in implementing strategies, because any strategic plan costs money, and deciding upon an appropriate mix of debt versus equity is a key strategic decision. Similarly, projected financial statement analysis is also a strategy implementation tool often used by companies to assess the expected impact of a strategic plan on the firm's financial statements. Additionally, as noted, corporate valuation is a key strategy-implementation tool because many firms routinely buy and sell segments and rivals and thus negotiate buy and sell prices; corporate valuation is thus a strategic decision commonly made in firms. Furthermore, since marketing can be overly costly, perceptual mapping is a strategy tool commonly used by companies and organizations to help decide how best to reach actual and potential customers when implementing a strategic plan. The special issue $A M L E$ articles provide very little (if any) mention of any strategy implementation tools or techniques, except Lindsay et al. (2018) reported that some strategy textbooks cover the organizational structure topic. There has been some prior research however that reveals the extent that functional-level business skills in areas such as finance and marketing are presently included and covered within leading strategic-management textbooks (David and David 2017). Such articles help professors close the gap between theory and practice in teaching the capstone course (Sheehan et al. 2018; Wilton 2008; Yang 2009).

\subsection{Strategy Evaluation \\ Step 7 Continually Evaluate Strategies}

The Grant and Baden-Fuller (2018) model does not acknowledge "strategy evaluation" to be a stage in the strategy process. However, as revealed in the proposed model, in the corporate world evaluating strategies is an essential activity that utilizes various tools and techniques such as the balanced scorecard and projected financial statements. Strategy evaluation is indeed the final stage in strategic management. Managers desperately need to know when particular strategies are not working well; strategy evaluation is the primary means for obtaining this information. All strategies are subject to future modification because external and internal factors constantly change.

Three fundamental strategy-evaluation activities are (1) reviewing external and internal factors that are the bases for current strategies, (2) measuring performance, and (3) taking corrective actions (David et al. 2020, p. 276). Strategy evaluation is needed because success today is no guarantee of success tomorrow! Perhaps the most commonly used strategic planning tool for evaluating strategies is the balanced scorecard, yet this term is mentioned only once in the entire special issue (David et al. 2020, p. 279).

\section{Discussion}

Turning strategic-management students into "theorists," we contend, is ineffective for teaching the capstone course for many reasons discussed in this paper. Thus, the proposed strategic management pedagogical model is important because it builds upon extensive previous literature and it incorporates appropriate theories, steps, and hard and soft employability skills. The model should provide ample opportunity for professors to integrate theory and practice in teaching the capstone course, and thereby help close the gap between graduates' skills and employers' requirements. 
In the capstone course, students near the point of time in their lives when they seek and accept full-time employment, so their attention turns to real world, practical issues and concerns. In the capstone business course, students are expected (usually) to display and apply employability skills in the functional areas of business as they develop, usually in a team setting, strategic plans for a wide variety of firms (Wall Street Journal 2013).

Theory is needed to the full extent that it supports the practice of strategic planning. The "ignore practice" philosophy however makes no sense in law school, pharmacy school, medical school, or business school. Publishers such as Pearson, McGraw-Hill, and Cengage increasingly require textbook authors to provide coverage of employability skills. This requirement is in response to various accrediting organizations, as well as corporate executives and academicians, requiring that business courses better prepare students to enter the working world (Berdrow and Evers 2010; French et al. 2015). In this vein, we offer Figure 1 as a new, theoretical, practical, literature-derived framework that can serve as a baseline effective approach for teaching the capstone course.

Corporate executives and many business professors ask that the capstone course live up to its reputation for being the course that integrates all business functions and develops both soft and hard business skills among students nearing entry into the workforce (Cappelli et al. 1997; Beard et al. 2008; French et al. 2015; Marsh and Bishop 2014; Wegman et al. 2018). Hopefully the discussion provided herein will have a positive influence upon management education generally and strategic-management pedagogy in particular.

We suggest that strategic-management educators explicitly consider and actively incorporate employability skills as they design course materials. What we advocate is not a return to the traditional business policy course that was common in the 1960s, 1970s, and 1980s, but rather to augment or supplement that approach with new strategic planning hard and soft skills utilized by companies and organizations to actually formulate and implement strategic plans.

\section{Limitations and Direction for Future Research}

Although the seven steps illustrated in Figure 1 are commonly accepted in the practice of strategic planning, empirical evidence is needed to enhance and refine the model. A factor analysis, for example, regarding the "soft" employability skills would be helpful to condense the many skills included in the model into a manageable set of attributes needed to meet employers' expectations. Additionally, to further improve the proposed model, input is needed from academicians that teach marketing, finance, accounting, and management information systems to identify other "hard" skills deemed especially important to be included in teaching a capstone course.

By nature of this paper being heuristic rather than empirical, primary data aimed at investigating the relative importance of various hard and soft employability skills across varied industries and workplace environments is needed. To this end, and in anticipation of future research needed to empirically examine the proposed pedagogical model's effectiveness both in academic and business settings, we offer a sampling of research questions that need to be addressed in the future. Provided in Table 1, five research questions with associated rationales are given in order to help pave the way for a smooth transition to more practicality in teaching the capstone business course. 
Table 1. Strategic management pedagogical questions for future research.

Academic ( $\mathrm{Q}=$ question; $\mathrm{R}=$ rationale)
Q1-In teaching the capstone strategic management course, how do lecture, case analysis, and
simulations compare in terms of effectiveness in students developing "soft" (and "hard")
employability skills as included in the proposed model?

R1-Three common pedagogical methods used in teaching strategic management are lecture, case analysis, and simulations. Future research is needed to examine various pedagogical approaches to determine the best means or mix of approaches to facilitate a shift towards practicality to better align graduates' skills with employers' expectations.

Q2-What foundational strategic management theories included in Figure 1 are most useful for enhancing development of "soft" (and "hard") employability skills among capstone strategic management students?

R2-Theory is useful in teaching strategic management to the extent that such concepts enhance practicality. For example, discussion related to RBV theory could enhance students' understanding of the value chain concept and the need to assess competitive advantage/disadvantage from the bottom (raw materials) to the top (customer purchase) of the chain. Accordingly, empirical evidence regarding the effectiveness of various theories in developing students' skills is needed.

Q3-Across the stages of strategic management (formulation, implementation, and evaluation), what soft and hard skills can be honed to excellence more readily.

R3-Many strategic management textbooks and classes are organized around the three stages seen in Figure 1, so insight regarding when, how, and why to focus on development of various skills would be helpful for professors as they shift to more practicality in teaching the capstone course.

Business $(\mathrm{Q}=$ question; $\mathrm{R}=$ rationale)

Q4-What is the relative importance of the "soft" (and "hard") employability skills included in Figure 1 for lower-level, middle-level, and top-level job placement?

R4-Empirical evidence is needed from practicing business managers regarding the relative importance of various "soft" (and "hard") employability skills across levels of management to enable academicians to be more effective in pedagogical approach for assuring student competence in these areas.

Q5-What is the relative importance of the "soft" (and "hard") employability skills included in Figure 1 for managers in profit vs. nonprofit organizations and small vs. large firms?

R5-Empirical evidence is needed from practicing business managers regarding the relative importance of various "soft" (and "hard") employability skills across levels of management to enable academicians to be more effective in pedagogical approach for assuring student competence in these areas.

\section{Conclusions}

Based on our literature review and experience teaching strategic management and helping companies develop strategic plans, we propose that capstone business students learn "how to do strategic planning." We propose giving strategy students the opportunity to fulfill the promise of their capstone course which is to apply functional-level business skills learned in prior business courses, and additionally, to learn new strategic planning skills valued and practiced in the workplace. To learn "how to do strategic planning" is a dream come true for many strategic management students. Enabling students to fulfill that dream is a worthy goal for management educators as they hopefully/continually strive to narrow the gap between graduates' skills and employers' requirements. We provide an integrative, new, skills-oriented model that can facilitate a transition back towards practicality in teaching strategic management for the mutual benefit of both graduates and employers while maintaining some strategy theory for consideration as desired. 
Author Contributions: Conceptualization, M.E.D., F.R.D. (Fred R. David) and F.R.D. (Forest R. David); formal analysis F.R.D. (Fred R. David) and F.R.D. (Forest R. David); writing, M.E.D. and F.R.D. (Fred R. David). All authors have read and agreed to the published version of the manuscript.

Funding: This research received no external funding.

Conflicts of Interest: The authors declare no conflict of interest.

\section{References}

AACSB. 2020. Available online: https:/ / www.aacsb.edu/about/mission (accessed on 22 April 2020).

Alamo-Vera, Francisca Rosa, Lidia Herndandez-Lopez, Jose Luis Ballesteros-Rodrigues, and Petra De Saa-Perez. 2020. Competence development and employability expectations: A gender perspective of mobility programmes in higher education. Administrative Sciences 10: 74. [CrossRef]

Barney, Jay. 1991. Firm resources and sustained competitive advantage. Journal of Management 17: 99-120. [CrossRef]

Barney, Jay B. 1995. Looking inside for competitive advantage. Academy of Management Perspectives 9: 49-61. [CrossRef]

Barney, Jay B., and Alison Mackey. 2018. Monopoly profits, efficiency profits, and teaching strategic management. Academy of Management Learning and Education 17: 359-73. [CrossRef]

Beard, Debbie, Dana Schwieger, and Ken Surendran. 2008. Integrating Soft Skills Assessment through University, College, and Programmatic Efforts at an AACSB Accredited Institution. Journal of Information Systems Education 19: 229-40.

Bell, Greg R., Igor Filatotchev, Ryan Krause, and Michael Hitt. 2018. Opportunities and challenges for advancing strategic management education. Academy of Management Learning and Education 17: 233-40. [CrossRef]

Bennis, Warren, and Jim O'Toole. 2005. How business schools lost their way. Harvard Business Review 83: 96-104.

Berdrow, Iris, and Frederick T. Evers. 2010. Bases of competence: An instrument for self and institutional assessment. Assessment $\mathcal{E}$ Evaluation in Higher Education 35: 419-34.

Boselie, Paul, Graham Dietz, and Corine Boon. 2005. Commonalities and contradictions in HRM and performance research. Human Resource Management Journal 15: 67-94. [CrossRef]

Bower, Joseph L. 2008. The teaching of strategy: From general manager to analyst and back again? Journal of Management Inquiry 17: 269-75. [CrossRef]

Boyd, Brian K., and Elke Reuning-Elliott. 1998. A measurement model of strategic planning. Strategic Management Journal 19: 181-92. [CrossRef]

Bridgman, Todd, Colm McLaughlin, and Stephen Cummings. 2018. Overcoming the problem with solving business problems: Using theory differently to rejuvenate the case method for turbulent times. Journal of Management Education 42: 441-60. [CrossRef]

Buckley, Peter J. 2018. How theory can inform strategic management education and learning. Academy of Management Learning and Education 17: 339-58. [CrossRef]

Campbell, Noel D., Kirk C. Heriot, and Zachary R. Finney. 2006. In defense of silos: An argument against the integrative undergraduate business curriculum. Journal of Management Education 30: 316-32. [CrossRef]

Cappelli, Peter, Laurie Bassi, Harry Katz, David Knoke, Paul Osterman, and Michael Useem. 1997. Change at Work. New York: Oxford University Press.

Carson, James Taylor. 2019. Blueprints of distress?: Why quality assurance frameworks and disciplinary education cannot sustain a 21st-century education. Teaching in Higher Education 24: 1014-23. [CrossRef]

Cochran, Daniel S., and Fred R. David. 1986. Communication effectiveness of organizational mission statements. Journal of Applied Communication Research 14: 108-18. [CrossRef]

David, Fred R. 1986. The strategic planning matrix-A quantitative approach. Long Range Planning 19: 102-7. [CrossRef]

David, Meredith E., and Fred R. David. 2017. Are key marketing topics adequately covered in strategic management? Journal of Strategic Marketing 25: 405-17. [CrossRef]

David, Fred R., Meredith E. David, and Forest R. David. 2011. What are business schools doing for business today? Business Horizons 54: 51-62. [CrossRef]

David, Forest R., Fred R. David, and Meredith E. David. 2016a. Benefits, characteristics, components, and examples of customeroriented mission statements. International Journal of Business, Marketing, and Decision Sciences 9: 1-14.

David, Meredith E., Fred R. David, and Forest R. David. 2016b. The Quantitative Strategic Planning Matrix (QSPM): A new marketing tool. Journal of Strategic Marketing 3: 1-11.

David, Fred R., Steven A. Creek, and Forest R. David. 2019. What is the key to effective SWOT analysis? Including AQCD factors. SAM Advanced Management Journal 84: 25-36.

David, Fred R., Forest R. David, and Meredith E. David. 2020. Strategic Management Concepts and Cases-A Competitive Advantage Approach, 17th ed. Hoboken: Pearson Education.

DiMaggio, Paul, and Walter Powell. 1983. The iron cage revisited: Institutional isomorphism and collective rationality in organizational fields. American Sociological Review 48: 147-60. [CrossRef]

DiMaggio, Paul, and Walter Powell. 1991. The New Institutionalism in Organizational Analysis. Chicago: University of Chicago Press.

Donaldson, Lex. 2002. Damned by our own theories: Contradictions between theories and management education. Academy of Management Learning and Education 1: 96-106. [CrossRef] 
du Toit, A. 2016. Using environmental scanning to collect strategic information: A South African survey. International Journal of Information Management 36: 16-24. [CrossRef]

Edudemic. 2013. The 7 Skills Students Must Have for the Future. Available online: http://www.edudemic.com/the-7-skills-studentsmust-have-for-the-future (accessed on 8 July 2013).

Fehringer, Dale, Bonnie Hohhof, and Ted Johnson. 2006. State of the Art: Competitive Intelligence. Washington: Competitive Intelligence Foundation.

Forbes. 2012. The 10 Skills That Will Get You Hired in 2013. Available online: http:/ /www.forbes.com/sites/meghancasserly/2012/1 2/10/the-10-skills-that-will-get-you-a-job-in-2013/ (accessed on 10 July 2014).

Foster, Pacey, and Inga Carboni. 2009. Using student-centered cases in the classroom: An action inquiry approach. Journal of Management Education 33: 676-98. [CrossRef]

French, Erica, Janis Bailey, Elizabeth van Acker, and Leigh Wood. 2015. From mountaintop to corporate ladder-what new professionals really really want in a capstone experience! Teaching in Higher Education 20: 767-82. [CrossRef]

Frentzel, William Y., John M. Bryson, and Barbara C. Crosby. 2000. Strategic planning in the military: The US Naval Security Group changes its strategy, 1992-1998. Long Range Planning 33: 402-29. [CrossRef]

Ghannadian, Frank. 2013. BizEd Magazine. What Employers Want, What We Teach. Available online: http:/ / www.bizedmagazine. $\mathrm{com} /$ features/articles/what-employers-want-what-we-teach.asp (accessed on 10 August 2014).

Gilinsky, Armand, and Richard Robinson. 2008. A proposed design for the business capstone course with emphasis on improving students' information competency. Journal of Management Education 32: 400-19. [CrossRef]

Gonzalez, Jose Maria, Jose Luis Arquero Montaño, and Trevor Hassall. 2014. The change towards a teaching methodology based on competences: A case study in a Spanish university. Research Papers in Education 29: 111-30. [CrossRef]

Gosling, Jonathan, and Henry Mintzberg. 2004. The education of practicing managers. MIT Sloan Management Review 45: 19-22.

Grant, R. M. 2008. Why strategy teaching should be theory-based. Journal of Management Inquiry 17: 276-81. [CrossRef]

Grant, Robert M., and Charles Baden-Fuller. 2018. How to develop strategic management competency: Reconsidering the learning goals and knowledge requirements of the core strategy course. Academy of Management Learning and Education 17: 322-38. [CrossRef]

Greiner, Larry E., Arvind Bhambri, and Thomas G. Cummings. 2003. Searching for a strategy to teach strategy. Academy of Management Learning E Education 2: 402-20.

Gunn, Rod, and Wil Williams. 2007. Strategic tools: An empirical investigation into strategy in practice in the UK. Strategic Change 16: 201-16. [CrossRef]

Hanney, Roy. 2018. Doing, being, becoming: A historical appraisal of the modalities of project based learning. Teaching in Higher Education 23: 769-83. [CrossRef]

Hansen, Drew. 2011. Forbes_Business Schools Have an Identity Crisis. Available online: http:/ /www.forbes.com/sites/drewhansen/ 2011/10/04/why-mba-business-school-not-leaders / (accessed on 30 June 2012).

Jensen, Michael C., and William H. Meckling. 1976. Theory of the firm: Managerial behavior, agency costs and ownership structure. Journal of Financial Economics 3: 305-60. [CrossRef]

Lebron, Mariana J., David Brannon, Douglas Sanford, and Lori Ellison. 2020. Applying theory to practice: Implementing a live case competition in a capstone strategic management course. Journal of Management Education 44: 66-100. [CrossRef]

Lindsay, Sarah, Gavin Jack, and Veronique Ambrosini. 2018. A critical diversity framework to better educate students about strategy implementation. Academy of Management Learning and Education 17: 241-58. [CrossRef]

Marsh, Sarah J., and Terrence R. Bishop. 2014. Competency modelling in an undergraduate management degree program. Business Education \& Accreditation 6: 47-60.

Meyer, John, and Brian Rowan. 1977. Institutionalized organizations: Formal structure as myth and ceremony. American Journal of Sociology 83: 340-63. [CrossRef]

Mintzberg, Henry. 1990. The design school: Reconsidering the basic premises of strategic management. Strategic Management Journal 11: 171-95. [CrossRef]

Mintzberg, Henry. 2004. Managers, Not MBAs: A Hard Look at the Soft Practice of Managing and Management Development. San Francisco: Berrett-Koehler Publishers.

Moschieri, Caterina, and Juan Santalo. 2018. The impact of research performance on students' evaluation of strategy professors in business school. Academy of Management Learning and Education 17: 302-21. [CrossRef]

Mtawa, Ntimi, Samuel Fongwa, and Merridy Wilson-Strydom. 2019. Enhancing graduate employability attributes and capabilities formation: A service-learning approach. Teaching in Higher Education 1: 1-17. [CrossRef]

Paauwe, J. 2004. HRM and Performance: Unique Approaches for Achieving Long Term Viability. Oxford: Oxford University Press.

Paauwe, Jaap, and Paul Boselie. 2007. HRM and societal embeddedness. In The Oxford Handbook of Human Resource Management. Edited by Boxall Peter, John Purcell and Patrick M. Wright. Oxford: Oxford University Press, pp. 166-84.

Pearce, J. A., II, and Fred David. 1987. Corporate mission statements: The bottom line. Academy of Management Executive 1: 109-16. [CrossRef]

Peng, Mike W., Huy Will Nguyen, Joyce Wang, and Jason Shay. 2018. Bringing institutions into strategy teaching. Academy of Management Learning and Education 17: 259-78. [CrossRef] 
Perera, Srinath, Solomon Olusola Babatunde, John Pearson, and Damilola Ekundayo. 2017. Professional competency-based analysis of continuing tensions between education and training in higher education. Higher Education, Skills and Work-Based Learning 7: 92-111. [CrossRef]

Pfeffer, Jeffrey, and Christina T. Long. 2002. The end of business schools? Less success than meets the eye. Academy of Management Learning and Education 1: 78-95. [CrossRef]

Pilz, Matthias, and Lea Zenner. 2018. Using case studies in business education to promote networked thinking: Findings of an intervention study. Teaching in Higher Education 23: 325-42. [CrossRef]

Porter, Michael E. 1980. Competitive Strategy: Techniques for Analyzing Industries and Companies. New York: Free Press.

Powell, Thomas C. 1992. Strategic planning as competitive advantage. Strategic Management Journal 13: 551-58. [CrossRef]

Priem, Richard L. 2018. Toward becoming a complete teacher of strategic management. Academy of Management Learning and Education 17: 374-88. [CrossRef]

Rassuli, A., P. Bingi, A. Karim, and O. Chang. 2012. A survey of critical knowledge and skills of business school graduates: Employer perspectives. The Journal of International Management Studies 7: 1-6.

Reibstein, David J., George Day, and Jerry Wind. 2009. Guest editorial: Is marketing academia losing its way? Journal of Marketing 73: 1-3. [CrossRef]

Rendtorff, Jacob Dahl. 2015. Case studies, ethics, philosophy, and liberal learning for the management profession. Journal of Management Education 39: 36-55. [CrossRef]

Rippin, Ann, Charles Booth, Stuart Bowie, and Judith Jordan. 2002. A Complex Case: Using the case study method to explore uncertainty and ambiguity in undergraduate business education. Teaching in Higher Education 7: 429-41. [CrossRef]

Ruth, Damian. 2014. Teaching strategy: Reflections on professional practice. Teaching in Higher Education 19: 254-65. [CrossRef]

Schneider, Marguerite, and Pamela Lieb. 2004. The challenges of teaching strategic management: Working toward successful inclusion of the resource-based view. Journal of Management Education 28: 170e187. [CrossRef]

Sheehan, Norman T., Mahendra R. Gujarathi, Joanne C. Jones, and Fred Phillips. 2018. Using design thinking to write and publish novel teaching cases: Tips from experienced case authors. Journal of Management Education 42: 135-60. [CrossRef]

Strive and Grind. 2013. 6 Skills All College Graduates Should Have. Available online: http:/ /strivengrind.com/6-skills-all-collegegraduates-should-have/ (accessed on 20 June 2016).

Thomas, Anisya S. 1998. The business policy course: Multiple methods for multiple goals. Journal of Management Education 22: 484-97. [CrossRef]

Uyar, Ali, and Ali Haydar Gungormus. 2011. Professional knowledge and skills required for accounting majors who intend to become auditors: Perceptions of external auditors. Business and Economics Research Journal 2: 33-49.

Wall Street Journal. 2013. Why Aren't Companies Getting Graduates with Skills They Need? Available online: http:/ / online.wsj.com/ news/articles/SB10001424052702304561004579135253438812772 (accessed on 14 October 2013).

Wegman, Lauren A., Brian J. Hoffman, Nathan T. Carter, Jean M. Twenge, and Nigel Guenole. 2018. Placing job characteristics in context cross-temporal meta-analysis of changes in job characteristics since 1975. Journal of Management 44: 352-86. [CrossRef]

Wilton, Nick. 2008. Business graduates and management jobs: An employability match made in heaven? Journal of Education and Work 21: 143-58. [CrossRef]

Wolf, Carola, and Steven W. Floyd. 2017. Strategic planning research: Toward a theory-driven agenda. Journal of Management 43: 1754-1788. [CrossRef]

Yang, Min. 2009. Making interdisciplinary subjects relevant to students: An interdisciplinary approach. Teaching in Higher Education 14: 597-606. [CrossRef] 